\section{A South African bibliography to the year 1925. Volume 6: subject and title indexes (Grey bibliographies, no. 2)}

\author{
Rossouw, Fransie, comp. \\ Cape Town: South African Library \\ 1997
}

ISBN 0-86968-122-2

Hard cover, 514p.

R250. 00 plus $\mathrm{R} 25.00$ registered postage

South Africa's distinguished bibliographical record has for many years been widely accepted as being the best on the African continent. Within the country itself this factor is regarded as a matter of professional pride.

In the field of retrospective national bibliography, the South African Library, one of two national libraries, has for long excelled in the production of world-class bibliographies. The sixth (and presumably final) volume of $A$ South African bibliography to the year 1925 (acronym SABIB) is further proof of the Library's achievements.

The original set of four volumes of SABIB was published in $1979^{1}$ folllowed by a fifth, supplementary volume in 1991.2 The present sixth volume, consists of subject and title indexes to the work as a whole.

This sixth in-depth Index volume is a monumental achievement for several reasons. In the first instance, it is the first time that the pre-1925 Africana literature of South Africa has been so comprehensively and professionally indexed. Secondly, it is a boon to reference work in the field of Africana, greatly facilitating searches for bibliographical information. Thirdly, it will serve as an expert guide and role-model for African bibliographers intent on discovering the best methods of indexing African associated and orientated material. This applies particularly to the fields of subject analysis and indexing. It has always been notoriously difficult to provide a thorough, professional subject index to Africana, which by its nature is complex and befraught with difficulty. Numerous titles of publications in this field are at best vague and deceptive, and to provide a subject index it is vitally necessary for the indexer to be familiar with them, no mean feat in the case of a corpus of literature totalling some 35000 works.

The publication under review, and the set of which it forms part, stand as a monument to those who were responsible for its conception and creation. In the first instance, tribute must be paid to Douglas Varley, doyen of South African Bibliography and a former head of the South African Library, to whom the sixth volume is dedicated, 'for his vision and planning which brought this monumental national bibliography into being'. He has, throughout the whole period, taken an active interest in its progress.
Secondly, it should be noted that the publication of SAIBIB6, marks the culmination of Pieter Westra's term of office as director of the South African Library. It was under his inspired leadership that SABIB5 and now this much needed sixth volume, came into being as a fitting triumph to a distinguished career. Above all, however, it is the compiler Fransie Rossouw who deserves the greatest accolade. She has been a member of the SABIB team since its inception, more than 30 years ago. She has been involved in many other important national bibliographic projects, but it is this sixth volume of SABIB, which took seven years to compile, which stands as a testimony to her excellence as a national bibliographer.

Fransie Rossouw won the former SAILIS Award for bibliography in 1993 for the excellent standards achieved in the compilation of SABIB5 (Supplement). She has again excelled herself with this sixth volume, which she compiled single-handedly and supervised through to its successful publication, a Herculean task in itself. Equally important is the fact that the work conforms closely to international standards in following the Library of Congress Subject Headings as a basis, wisely adapted to previous SABIB practice and South African conditions.

The sixth volume of SABIB is indeed a formidable work and clearly a labour of love. The volume consists of 515 double-column pages and there are just over 50000 entries in all. Of these, 15000 are subject index entries, main and subheadings (including cross-references). The volume is user-friendly, attractively printed and sturdily bound, the cost having been met by the Douglas Varley Fund, established by the Friends of the South African Library, for acquisition and publication purposes. The price of R250.00 for one of the most prestigious and important national bibliographies of our time is certainly not excessive. It can in fact be considered modest in view of the exhorbitant cost of books generally, particularly in South Africa.

To sum up, the reviewer can do no better that quote Pieter Westra's concluding remarks in the preface to SABIB6: 'We trust that this Index will facilitate the better exploitation of South Africa's published heritage'. Indeed, it cannot, and should not be otherwise. There is no better way for a national library to celebrate the turn of a momentous century.

\section{REUBEN MUSIKER}

Professor Emeritus of Librarianship and Bibliography, University of the Witwatersrand, Johannesburg.

\section{Notes}

1. A South African bibliography to the year 1925. London: Mansell for the South African Library, 1979. Four vols. Distributed by the South African Library.

2. A South African bibliography to the Year 1925. Vol. 5: Supplement. Compilers: Fransie Rossouw and Elizabeth A. Vockerodt. Cape Town: South African Library, 1991. Reviewed in South African journal of library and information science, 60(2), 1992:130-131. 